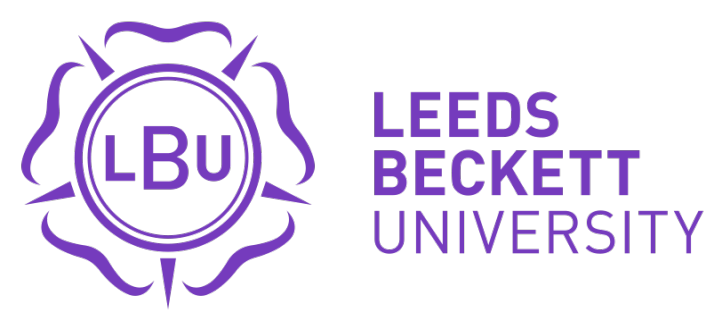

Citation:

Baster, D and Beresford, S and Jones, BT (2018) The 'brand' of the Catholic Church in England and Wales: challenges and opportunities for communications. Journal of Public Affairs. ISSN 1472-3891 DOI: https://doi.org/10.1002/pa.1881

Link to Leeds Beckett Repository record:

https://eprints.leedsbeckett.ac.uk/id/eprint/5398/

Document Version:

Article (Accepted Version)

The aim of the Leeds Beckett Repository is to provide open access to our research, as required by funder policies and permitted by publishers and copyright law.

The Leeds Beckett repository holds a wide range of publications, each of which has been checked for copyright and the relevant embargo period has been applied by the Research Services team.

We operate on a standard take-down policy. If you are the author or publisher of an output and you would like it removed from the repository, please contact us and we will investigate on a case-by-case basis.

Each thesis in the repository has been cleared where necessary by the author for third party copyright. If you would like a thesis to be removed from the repository or believe there is an issue with copyright, please contact us on openaccess@leedsbeckett.ac.uk and we will investigate on a case-by-case basis. 


\title{
The 'brand' of the Catholic Church in England and Wales: challenges and opportunities for communications
}

Baster, D.; Beresford, S.; Jones, B. T.

\begin{abstract}
This paper considers the concept of 'brand' in relation to religious organisations and, in particular, the Catholic Church in England and Wales. It explores the application of marketing and branding concepts to the Church and reports on perceptions of the Church's brand and identity. The findings show that the Catholic Church in England and Wales has very strong brand equity and high levels of brand loyalty among its members, although conventional marketing language should be avoided due to the sensitivities involved. The findings suggest that the Church could usefully be regarded as a 'brand community', akin in many key respects to brand communities in the commercial sphere. It recommends that Church communications could be enhanced by leveraging the brand more effectively as within a true 'brand community' for the purpose of encouraging brand loyalty and energising Church members.
\end{abstract}

Key words: Catholic church, brand communities, identity

\section{Introduction and context}

The present era has been described as the 'golden age of brands' (Twitchell, 1999) and yet, to many active members of religious organisations such as the Roman Catholic Church, the idea of applying terms such as 'brand' to their organisation seems inappropriate or even absurd (Cooke, 2008). Nevertheless, as Abreu (2006, p.141) writes, “A religious organisation is perceived by its constituents as a brand, a heterogeneous set of characteristics including its key message, the people who work for it, the place where the services take place, its equipment and all the associations of its offer." Given this fact, it is entirely reasonable for religious organisations to engage with their brand and utilise secular techniques and insights to ensure that it is harnessed as effectively as possible for the purposes for which the organisation exists. 
Religious organisations are not entirely theological or 'other-worldly' concepts for which brand is an alien concept. The Catholic Church in England and Wales is a distinct entity with its own unique historical and cultural influences. It has a central administrative hub (the Bishops' Conference Secretariat in London) as well as regional (diocesan) organisation and structures. Barth (2010, p. 782) points out, the Catholic Church "is an organisation with an established tradition and legitimacy grounded in public support that provides structure, offers guidelines for behaviour, and shapes human interaction". The aim of the paper is to apply the concept of brand to the Catholic Church so as to better understand how the Church presents itself through its communications and how its stakeholder groups perceive it and its message. One crucial question for the Church is, how can it express its message effectively in a mediadominated and largely secular culture? In seeking to address this question and the aforementioned aim, this paper, whilst aimed at practitioners, operates at the theory-practice interface and is theoretically underpinned with extant literature as well as being informed and shaped by Kapferer's (2008) 'Brand Identity Prism Model'.

It used to be the case that an organisation would seek to communicate its brand to its stakeholders in what might be termed a 'top-down' approach. However, the media landscape and the way in which brand is perceived have been transformed with the arrival of the internet and social media (Dietrich, 2014). Brands are no longer the property of the organisation seeking to communicate them, if indeed they ever were (Phillips and Young, 2009), but are co-created by all of an organisation's stakeholders or publics. In this sense, the brand of the Catholic Church in England and Wales is not just its message but the whole mix of its message, its identity, the way in which it is perceived by different stakeholder groups and its personality.

If, brands are about giving meaning to a product, a company or some other entity, then it should follow that discussion of how the concept of brand applies to religion should have received a good deal of scholarly attention because religion gives meaning to countless millions around the world. However, it fails to register in almost any mainline marketing textbook (Shepherd, 2004) and, while there are many scholarly works on a wide range of topics to do with brand, research on branding and other areas of marketing in religious organisations is very limited (Mottner, 2008). This paper provides new insights and furthers understanding in this area by drawing on the extant literature under the sub-headings 
'relationship between brand, religion, and self-identity', 'application of brand', 'purpose and method of marketing religion' and 'the Catholic brand'. Set against this body of literature survey research findings are reported on that cover relevant related sub-headed themes including 'understanding of the church's brand', 'the church's perceived characteristics', 'the church's brand personality', 'corporate reputation' and 'solutions'. The literature is again referred to and underpins further discussion of the primary research findings in the conlusions and recommendations. We begin the literature review with a brief discussion of Kapferer's (2008) 'Brand Identity Prism Model' which serves as the theoretical backdrop to the constructs discussed and the themes and issues that emerge from the literature and the primary data.

\section{Literature review}

\section{Introduction}

"Brand" is a contested and much discussed concept and the purpose here is not to enter into that complex debate but rather to focus in on certain features, aspects and elements. Kapferer's (2008) Brand Identity Prism Model is used to set the scene for the subsequent discussion and application of literature as well as analysis of primary data. It comprises six aspects and two dimensions. The six aspects are: 1] physique, 2] personality, 3] culture, 4] relationship, 5] reflection, and 6] self-image. The two dimensions into which these six aspects fall are 1] the constructed source versus the constructed receiver, and 2] externalisation versus internalisation. The European Institute for Brand Management (2009) describe the two dimensions in the following terms:

“a] The constructed source versus the constructed receiver: a well presented brand has to be able to be seen as a person (constructed source: physique and personality) and also has the stereotypical user (constructed receiver: reflection and self-image). b] Externalisation versus internalisation: a brand has social aspects that define its external expression (externalisation: physique, relationship and reflection) and aspects that are incorporated into the brand itself (internalisation: personality, culture and self-image)." 
The first of the six aspects is physique which looks at how the brand is recognised as well as its functionality and is the basis on which everything else is built. For the Catholic Church the brand is recognised amongst other things through God's representative on earth, the Pope and its functional offerings including that of salvation. Personality can be equated with the character of the brand and Catholic Church communication captures this perfectly. Culture as applied here can be said to refer to Roman Catholic values and Christian principles that together help convey the Catholic Church's brand identity. The relationship between the Catholic Church and followers of the Catholic faith is also important in helping to create and build brand identity. So too is reflection and as its focus is on practising Catholics but also on the wider Catholic family as part of the overall target group. Self-image is the final constituent element of Kapferer's brand identity prism model and for Catholics this is about being virtuous, good and living life according to the teachings of Jesus Christ as interpreted by Roman Catholicism. Kapferer's (2008) Brand Identity Prism Model provides the theoretical backdrop for situating the literature review and subsequent primary data findings.

\section{Relationship between brand, religion and self-identity}

The relationship between brands and religion is an area that has interested Shachar et al., (2011) and Einstein (2008) who write of a symbiotic relationship between marketing and religion, in that religion has become a product while products, in a sense, have become religions. Twitchell (2004) suggests that religion and marketing are virtually one and the same thing, while Usunier and Stolz (2014, p.4) ask, "Are then religions becoming brands while brands are becoming religions?"

We want to believe a product will make us better, just as we want to believe religion will. In fact, good marketing can look a lot like the process of religious conversion. Consumers take on brands as part of their personal identity and in turn become evangelists for the product (Einstein, 2008).

Shachar et al (2011) introduce the concept of 'brand reliance' to mean the value consumers place on the benefits they derive from brands. Whereas brand equity is a characteristic of a brand, brand reliance is a characteristic of the person using the brand. They then present evidence which suggests that religiosity (which they define as the degree to which a person 
believes in God or participates in the activities of a religious community) is negatively related to brand reliance. This is to say that people who are more religious are less likely to rely on brands to express aspects of their self-identity (on the basis that 'brand' in this sense applies only to commercial products and services). Shachar et al. thus conclude that "brands and religion function as substitutes in expressing self-worth" (2011, p.93).

The same point is made by Cutright et al. (2014) who argue that brands help individuals to maintain consistency between different aspects of self but that "brands and religion can activate distant and, at times, conflicting aspects of self" (p. 2209). This is because people perceive that the underlying goals and values of commercial brands and religion are very distant to one another. The key point here is that brands are a way of expressing identity, just as religions are to their adherents. Cătălina and Andreea (2014) describe brands as means of self-expression and as a 'lifestyle beacon' (p.104) and present research findings which suggest that consumers not only use brands as instruments for expressing their own identity but also for projecting an individualised image of their desired lifestyle. Chernev et al. (2011) similarly demonstrate that brands are used to express and validate a consumer's identity and also reaffirm their principles or beliefs. Thus brands of commercial products have often taken on religious traits. No more clearly is this the case that in so-called 'brand communities'. Members of brand communities venerate the product, feel an emotional bond to other brand users and engage in 'evangelistic' behaviour (Usunier and Stolz, 2014). Social identity theory can be used to explain how to divide people into groups and create rivalry because to form such communities is part of what it is to be human.

\section{Application of 'brand'}

Although the Christian Church has arguably been marketing itself since its inception, it was not until the beginning of the $20^{\text {th }}$ century that 'church marketing' can be identified as a specific concept in the academic literature (Mulyanegara et al., 2010, p. 340, citing Bartels, 1976) which still lacks a comprehensive theoretical foundation for how marketing concepts are related to church participation (ibid.). Indeed, there is scholarly disagreement over what type of marketing is concerned with religion. Some have described it as an example of 'nonprofit marketing', while others have opted instead for 'services marketing' or 'ideas marketing' (Shepherd, 2004). Voas (2014) prefers the term 'concept marketing'. Shepherd 
(2004) describes church marketing as 'naïve marketing' on the basis that churches have been engaged in marketing all along but without being aware of it.

It is clearly the case that the faith focus of religious organisations is a key element of their brand. For example for faith-based charities religious affiliation is central to their brand identity and they have a "personality distinctive from the balance of the sector" (Sargeant, 2009, p.172). Stewart Hoover (1996, cited in Einstein, 2008, p.74) argued that in today’s culture, religious practice constitutes "a situation of seekers turning to a largely commodified inventory of symbols, values and ideas out of which they appropriate those which fit best into senses of themselves".

The adoption of marketing methods from mainstream consumer marketing by religious organisations gradually accelerated during the second half of the 20th century (Shepherd, 2004). The definitions and attributes of a brand clearly apply to religious organisations, and Voas (2014) is sure that "there is little difficulty in applying the terminology of brands to religion" (p.xviii). While the core beliefs and mission of a religious organisation cannot easily change, various scholars agree that the tools of branding can be used to meet a church's goals and objectives. Mottner (2008) writes that brand image, personality, identity and name all serve to help position the brand in people's minds and are "powerful and effective tools that can help a religious organisation deliver its brand promise" (p.99).

\section{The purpose and method of marketing religion}

If branding as a tool of marketing is to be applied to religious organisations, then their very distinct character when compared to commercial organisations is likely to have a bearing on how branding is applied and for what purpose. This is partly due to the very particular sensitivities involved. In the commercial sphere, marketing and branding are tools with which to build market share and gain competitive advantage, as much as to encourage customer loyalty. Herein lies one of the problems of applying such concepts to religion, at least in the current age. Abreu (2006, p.140) writes, "Marketing is often misinterpreted, regarded as manipulative, misused, seen solely as a collection of advertising, promotion and selling tools, misunderstood and mistrusted. Marketing might even be seen as desacrilising religion." The fundamental challenge, therefore, is how to affirm the beliefs and claims of one's own 
religious faith while showing tolerance towards the beliefs and claims of others (Ratzinger, 2004).

Cutright et al. (2014) argue that the purpose of marketing and branding religion is not to gain more members but instead to serve an internal purpose of making religious commitment more stable and less susceptible to the influence of commercial brands. Their argument is that a religious brand can be utilised to retain and energise a religious group's members by cementing the group in its members' minds as key to their sense of identity. Abreu (2006) also makes the point that marketing within religious groups is an attempt to increase levels of satisfaction among their members. This objective is clearly seen in the way consumer brands position themselves as being able to fulfil the self-definitional needs of their consumers (Tildesley and Coote, 2009), so the same can be true of a religious brand.

How to do this without 'selling' the religion is something many members of religious groups would be unwilling to contemplate. Abela (2014) has proposed that appealing to the imagination is "an ethical and effective technique for marketing religion" (p.50). Abela defines this technique as "a type of marketing communication with aesthetic (visual), poetic (story form) and truthful (truths relevant to the audience) characteristics designed to engage the imagination of the target audience" (ibid.). This ties in with other definitions of branding, such as that of Usunier and Stolz (2014) who describe is as "identity-generating storytelling" (p.14).

\section{The Catholic brand}

Religion in Britain today has been described as a "toxic brand" (Witkin, 2014; Woodhead, 2014) and it is certainly under pressure. Voas (2014) likens religious leaders to cigarette manufacturers as religion has become associated in the public consciousness with a number of unpopular things. "It is not enough to show that the product is good of its kind; the brand manager must overcome some resistance to the kind of thing it is" (ibid., p. xvii).

The brand of the Catholic Church as perceived in England and Wales is no exception, of course, which is why Thompson (2013) can talk about Pope Francis "decontaminating the Catholic brand" which he believes has been badly damaged by the well-documented sexual 
abuse crises. While other faith communities may have embraced the tools of branding more obviously, such as the Church of England which has a clearly recognisable logo and engages in advertising (Guardian, 2015), the Catholic Church in England and Wales has not made such an effort. This is not to say, as has been demonstrated above, that it does not have a well developed brand.

Certainly the management of the Church in England and Wales does have a corporate communications department, has national and regional mechanisms to communicate its brand and considers communications to be an important part of its work (Nichols, 2015). By way of practical example the Diocese of Westminster has a website which describes the work of the church's Public Affairs Office (http://www.rcdow.org.uk/diocese/default.asp?library_ref=4\&content_ref=64). In addition to this the Catholic Church in England and Wales has a its own website (http://www.catholicew.org.uk/) and is an important part of its communication mix and offer. In addition to this there are a number of apps that are used to promote the values and ethos of the Catholic Church and examples include 'The Holy Rosary', 'Catholic Daily Reflections', and 'Catholic Daily Readings'. Yet there are many challenges encountered by faith organisations in presenting their brand positively. As Garcia (2010, p. 72) notes, "ultimately, so long as society's paradigm is secular", actions of the Church "will always generate misunderstandings among the media and the public opinion”.

An important consideration here is how the Catholic Church can rightly be defined in any case. While Barth (2010) describes it as an organisation in rather corporate terms, this may not be how many of its stakeholders perceive it. Stakeholders might perceive it more in terms of a way of life, a calling, a philosophy or even a celebrity cult, etc., and this would obviously have a significant bearing on their understanding of the Catholic brand.

\section{Research outlined}

In order to shed light on how the brand of the Catholic Church in England and Wales is perceived, how closely this corresponds to the brand identity that is projected by the institution itself, and how the Church can communicate its brand more effectively, a survey was conducted with the objectives being to: 
- Examine whether the concept of brand can be applied appropriately to faith communities such as the Catholic Church in England and Wales.

- Investigate the perception among different internal stakeholder groups of the brand of the Catholic Church in England and Wales, with particular reference to organisational image and reputation.

- Identify any opportunities based on the perception of its brand for the Church to communicate and leverage its brand equity more effectively.

While it is true that many would say non-Catholics are nevertheless stakeholders because the Church understands its mission as reaching out to everyone, this would have made the scope of this research too broad to be practicable. Therefore, the defined population for this research was those who self-identify as Catholics in England or Wales - regardless of how often they practise or whether they have a particular role within the Church.

The research involved the distribution of an online survey containing closed and free text questions intended to gather both quantitative and qualitative data. The survey questions were composed with regard to the preliminary literature review and, in particular, the work of Aaker (1997) who identified six distinct levels of meaning which a brand can convey to a consumer: the organisation's attributes, the functional and emotional benefits it offers, its values, its culture, its personality and the nature of its users.

The survey was distributed as widely as possible, to bishops, Diocesan Communications Officers and others with official roles within the Church within England and Wales, using contact details contained within the Catholic Directory for England and Wales (2016), and recipients were then encouraged to cascade it to their contacts more widely using 'snowballing'.

However, it should be noted that this research is exploratory and at this stage a truly representative sample of all stakeholders was not a main concern. As it was, 180 responses 
were received in total, all of whom identified as members of the Catholic Church in England and Wales. Responses were received from Catholics in all parts of England and Wales - from 19 of the Church's 22 dioceses - and were of diverse ages and life situations.

The work of Wymer et al. (2006) was useful in determining how to categorise the respondents in the initial survey questions on demographics. Wymer et al. (ibid.) identified four major stakeholder groups for non-profit organisations: input publics (people or organisations who provide resources and constraints); internal publics (staff and volunteers); partner or intermediary publics (agencies and other professionals who are hired or volunteer to further the organisation's aims); and consuming publics (in the case of a faith community, this is the population of believers). For this subject, this led to grouping respondents into three main categories of roles within the Church: Consecrated (bishops, priests, deacons, seminarians, non-ordained religious and other consecrated people), professionals (paid employees, Church contractors and Catholic journalists) and lay people (everyone else).

\section{Findings}

\section{Understanding of the Church's 'brand'}

The results of this survey indicate that one issue with applying the concept of brand to the Catholic Church is that Catholics themselves have widely different conceptions of what the Church actually is, and certainly it cannot be regarded in the same way as a commercial product might be by its consumers or customers. This is highlighted by the following responses: 


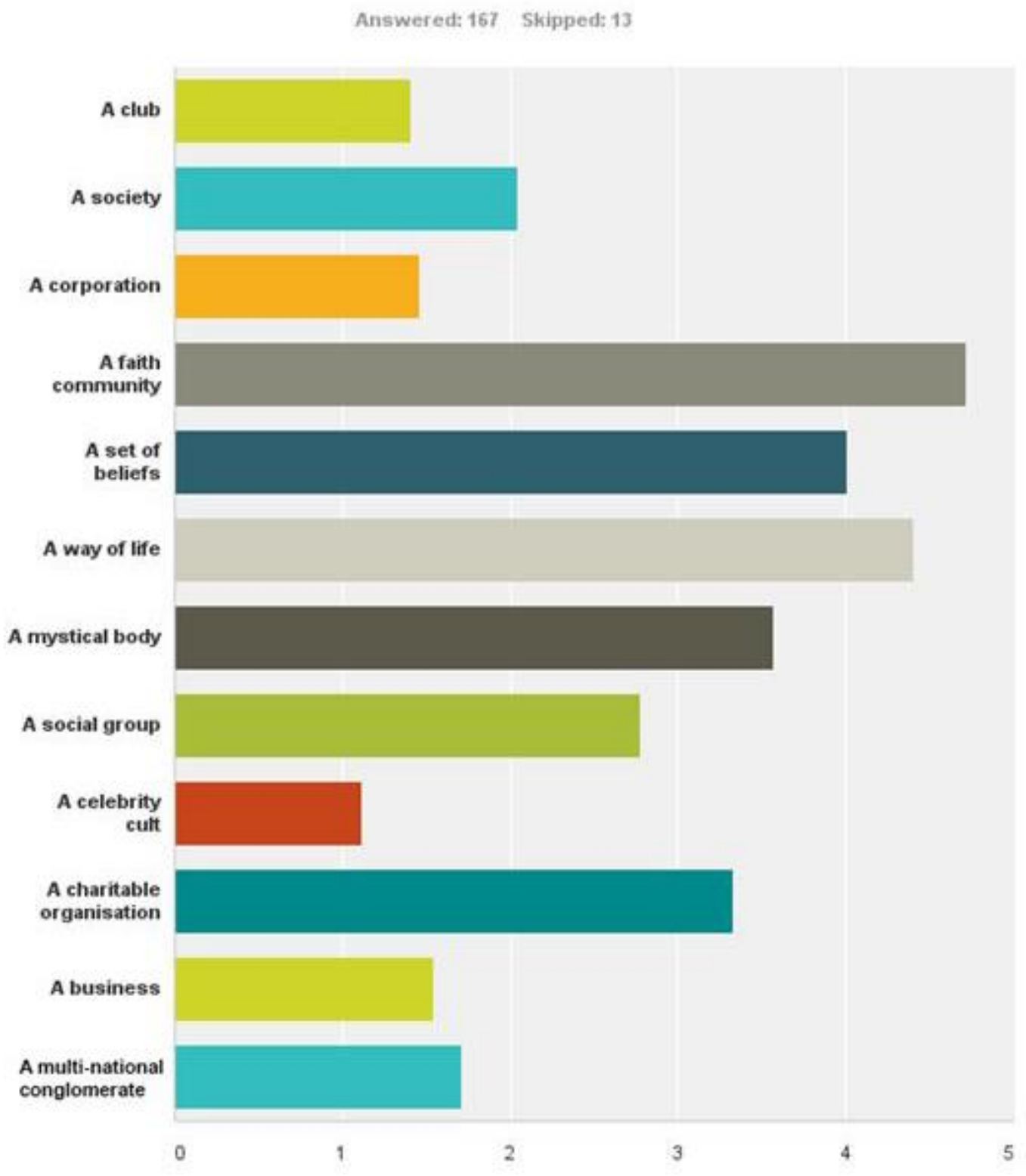

Table 1: Descriptions of the Catholic Church (Source: Authors)

The categories shown in Table 1 were suggested following conversations with Catholics and a review of relevant literature (for example, Cooke, 2008). Those who felt that none of these descriptions accurately described their understanding of what the Church is gave a wide variety of responses when asked to enter their own description. Responses ranged from theological descriptions such as "the Bride of Christ" and "a Pilgrim People" to more familiar terms such as "a family" and "an international community". 
When it came to introducing the concept of the Church's brand (both internationally and for England and Wales in particular), the majority of respondents had not previously considered it. Among those who had, considerably more had considered the worldwide Catholic Church to have a brand (30.1\%) than the Catholic Church in England and Wales to have its own district brand $(20.8 \%)$.

Given that many respondents had not considered the Church's 'brand', and that many people's understanding of the nature of the Church is of an entity that it entirely different from any kind of commercial organisation, it is not surprising that there is hostility to the application of marketing and branding techniques to the Church. However, the majority do not regard it as inappropriate and nearly half believe it is appropriate.

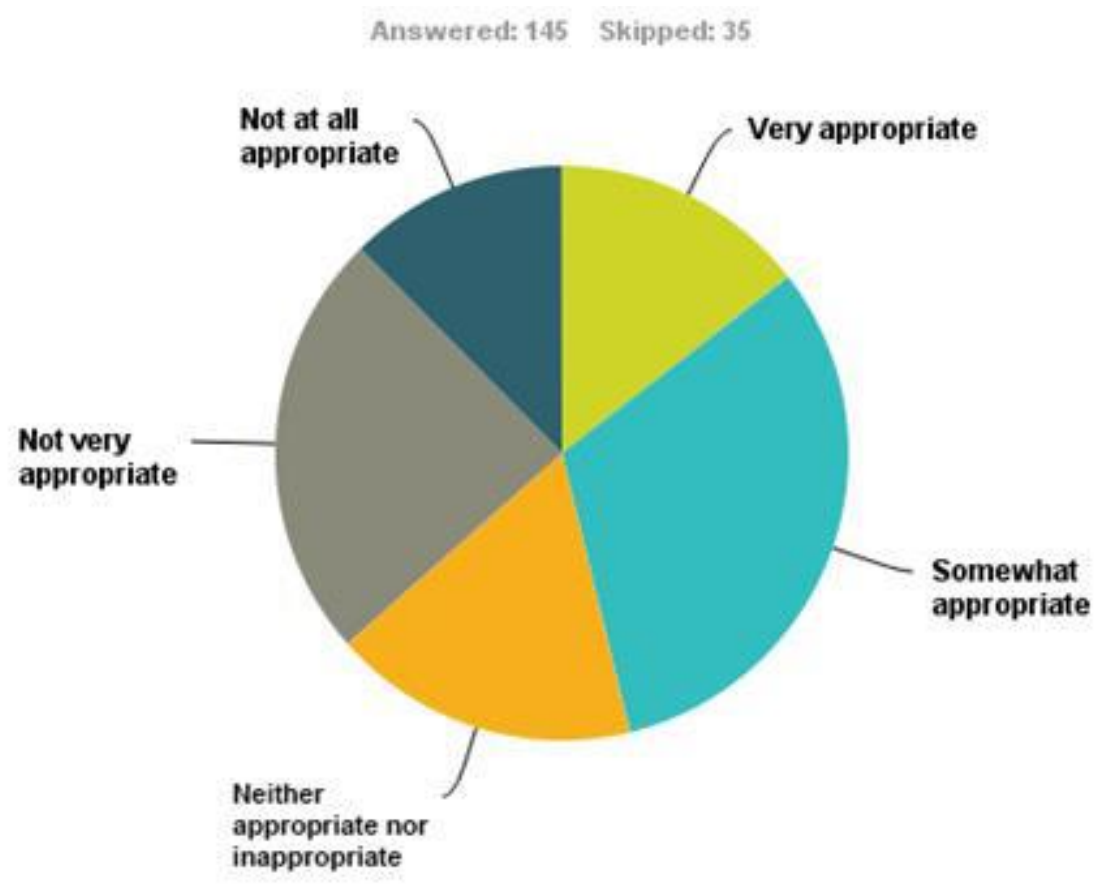

Table 2: Catholic Church, marketing, branding and communication (Source: Authors)

Here are three typical responses:

“...the catholic church should not be strategically marketed by any means or activity, we need to learn to be truthful which brand marketing is not." (married lay woman aged 41-64) 
"I think the concept [of] brand and the associated idea of marketing is profoundly inappropriate." (religious sister aged 41-64)

"If the church used marketing and branding techniques I would leave it." (lay married woman aged 41-64)

\section{The Church's perceived characteristics}

Respondents were asked to briefly state words that sprang to mind when thinking about the main characteristics of the Catholic Church in England and Wales:

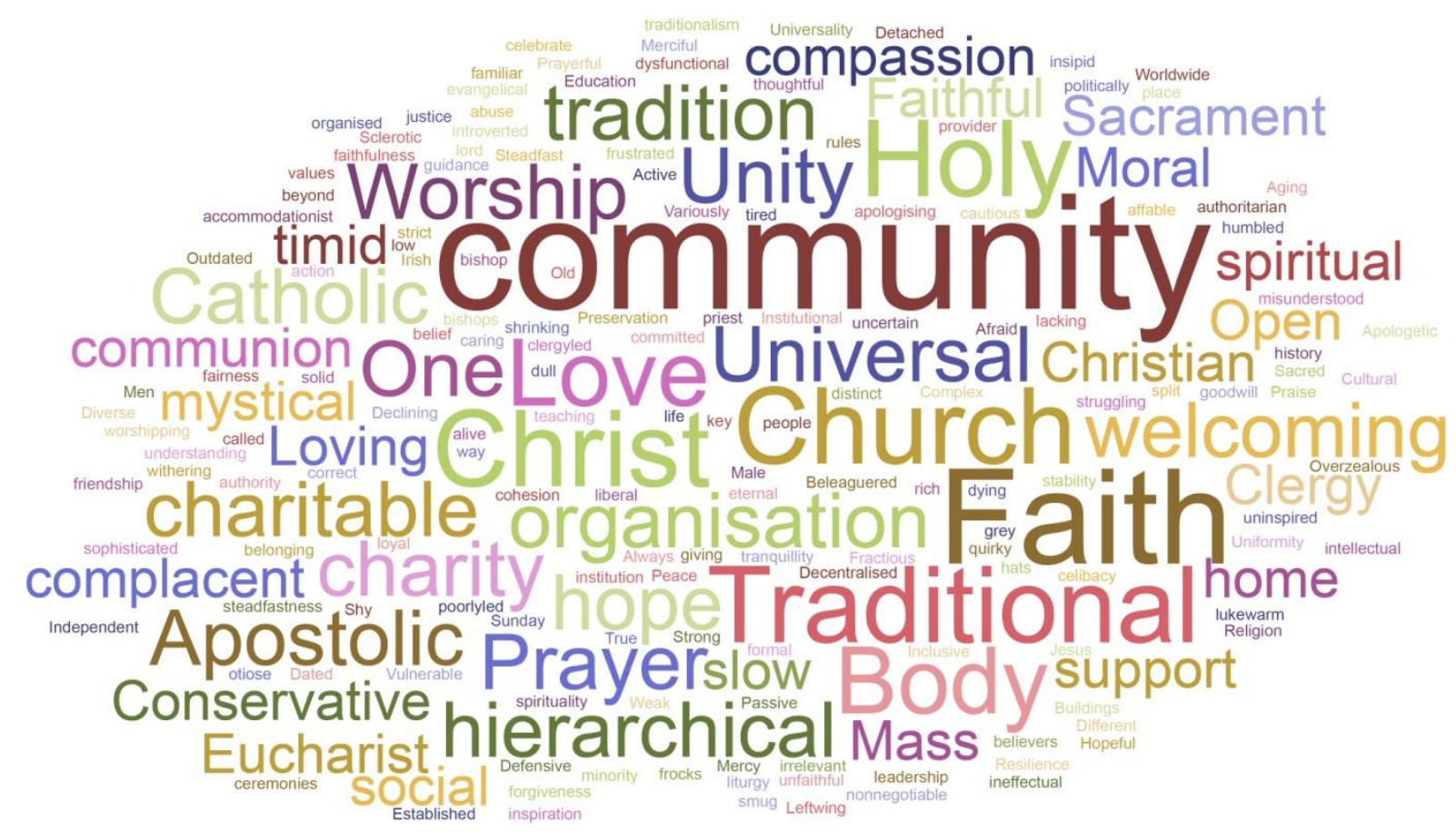

Figure 1: Main characteristics of the Catholic Church (Source: Authors)

The majority of responses here reflect the purpose of the Church as a religious organisation (e.g. worship, prayer and faith) although the sense of it being a community that is welcoming 
and socially active (charitable, social) is also a big common response. Some respondents do not see the characteristics so positively, however, and point to perceived negative characteristics such as complacency and timidity.

Respondents were also asked to briefly state words that came to mind when thinking about the benefits offered by church membership.

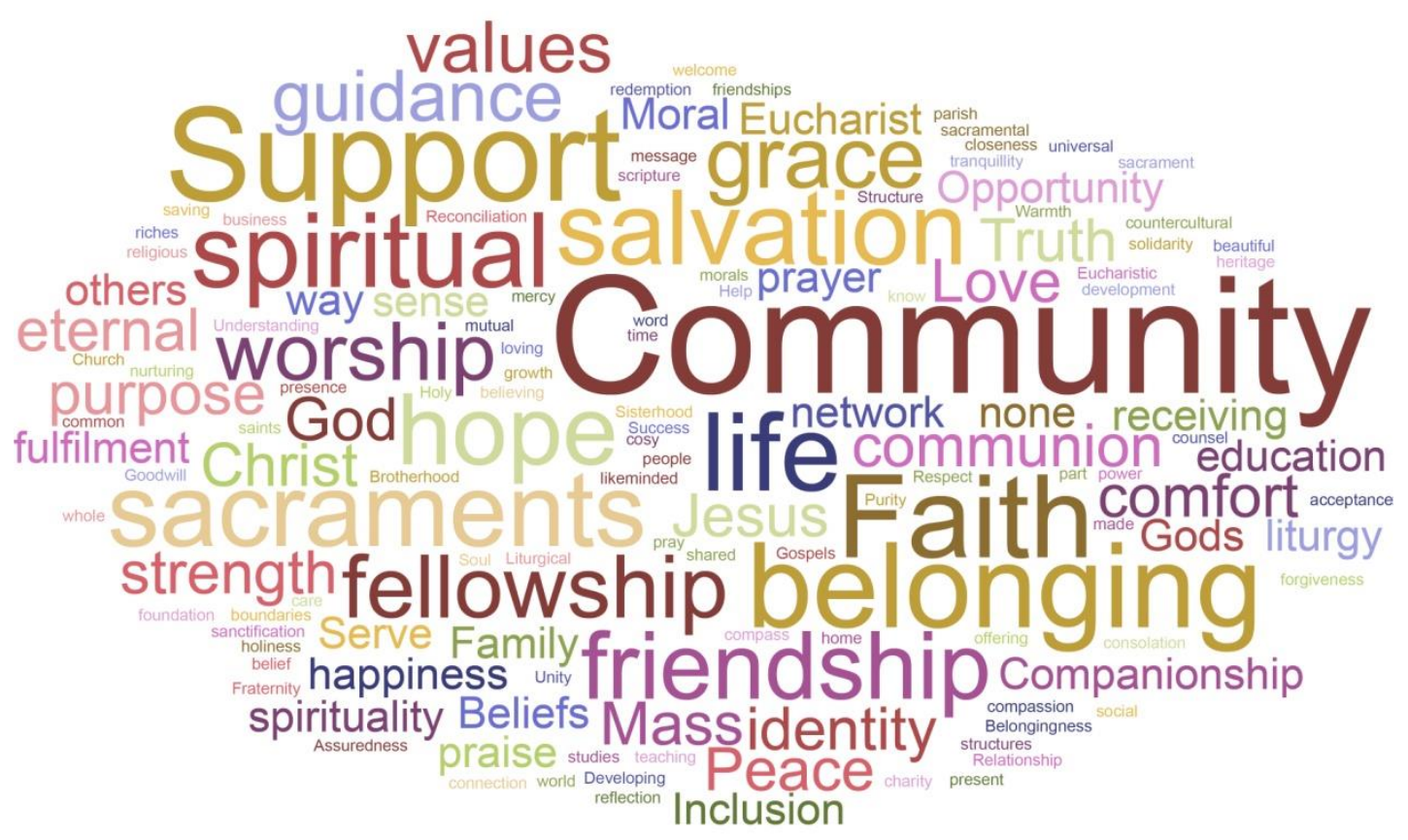

Figure 2: Benefits of church membership (Source: Authors)

The sense of the Church as a community of mutual support that was apparent in the previous question comes out even more clearly here, and may help to explain why membership of the Church is generally so important to respondents. Words mentioned often included 'community', 'support', 'faith', 'belonging' and 'spiritual'.

Words used to describe the prevailing characteristics of Church members are shown in Figure 3. 


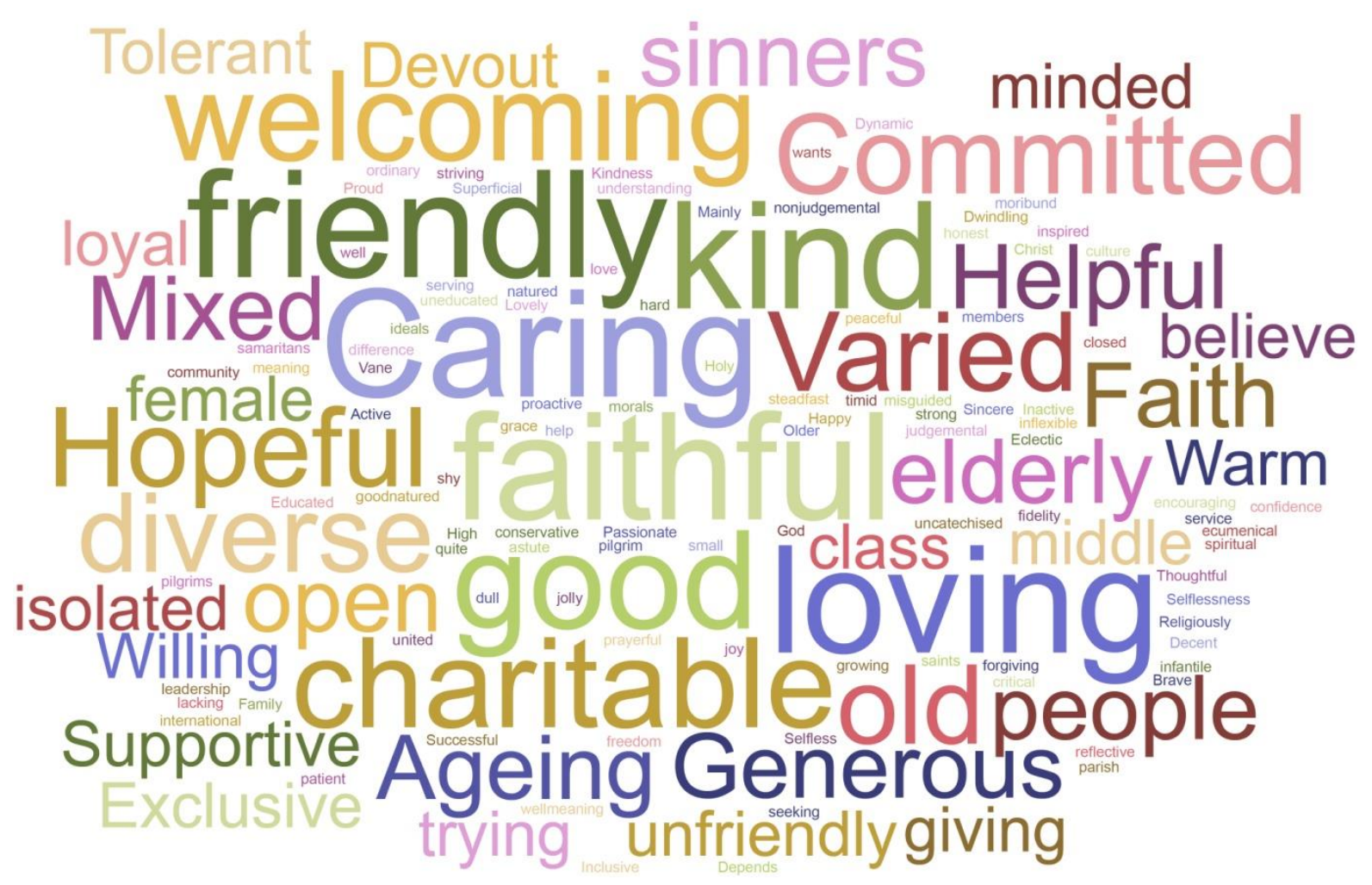

Figure 3: Characteristics of church members (Source: Authors)

There is a diversity of opinion when it comes to perceptions of the characteristics of Church members. There are many positive descriptions such as 'friendly', 'caring' and 'kind', but the perceived ageing demographic profile is cited by a number of respondents, while some see their fellow Church members as 'unfriendly' and 'isolated'.

\section{The Church's brand personality}

In order to understand people's perception of the Catholic brand more deeply, respondents were asked about the Church's personality. In a list of different personality traits, the

more positive personality traits were generally the most commonly chosen (such as the top three of 'charitable', 'welcoming' and 'generous'), although a significant number of respondents also felt that the Church was lacking in confidence, old-fashioned, out of touch and slow. Personality traits that one might expect to see more readily applied to commercial brands, such as 'imaginative', 'corporate' or 'exciting' are not commonly used to describe the Church, emphasising its very different nature. 


\section{Corporate reputation}

A religious organisation will have challenges in achieving a favourable brand perception in a primarily secular society. For the Catholic Church in particular, given well-documented scandals that have received considerable media attention, the challenge will be greater still. The question of how far this perception affects the Church's brand as understood by its own members can, therefore, be illuminating:

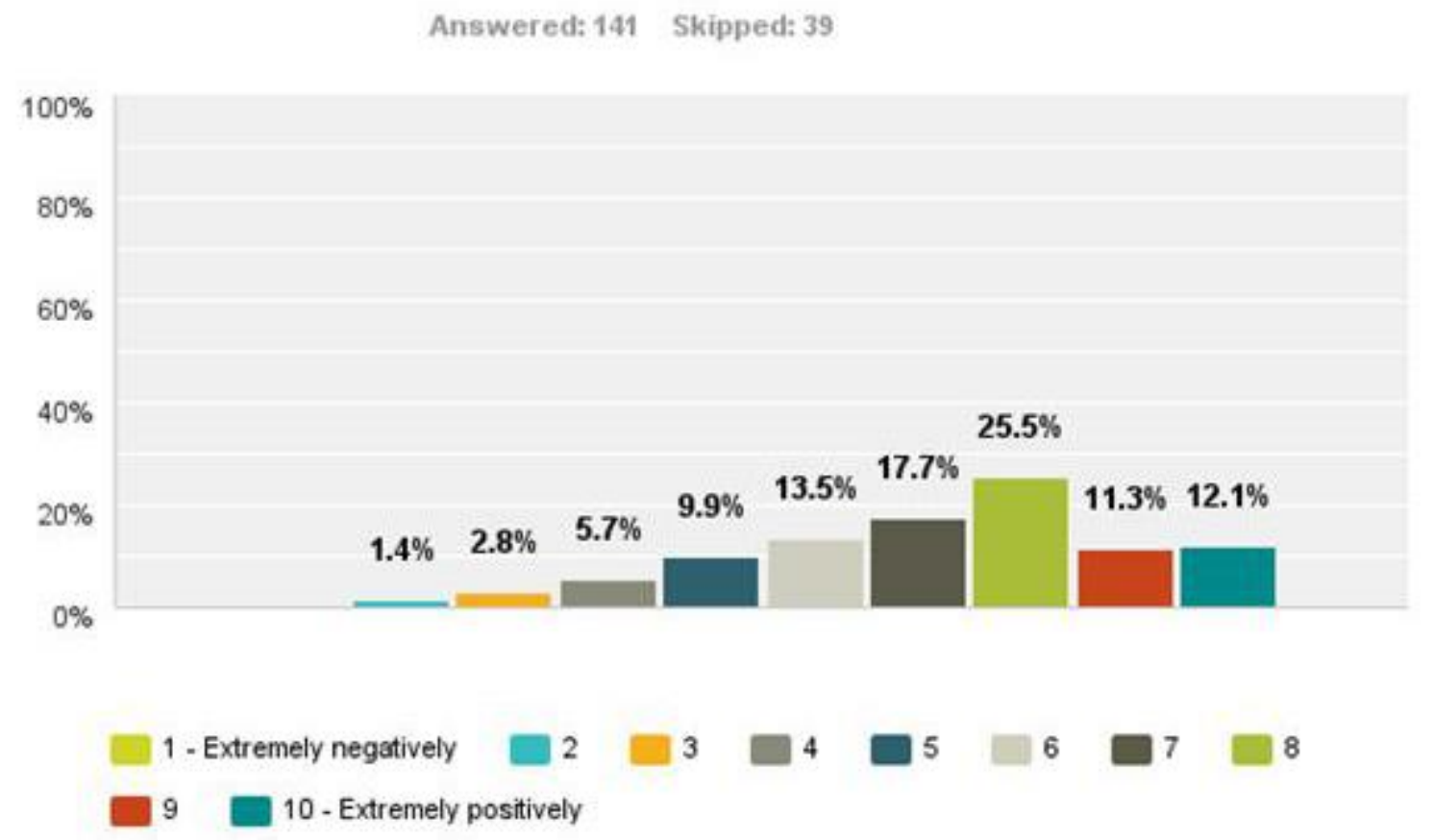

Table 3: Positive views of the Catholic Church in England and Wales (Source: Authors)

The mean average for this question is 7.16 , and the modal average 8 , which demonstrates that most Catholics have a positive view of their Church. 


\section{Answered: 141 Skipped: 39}

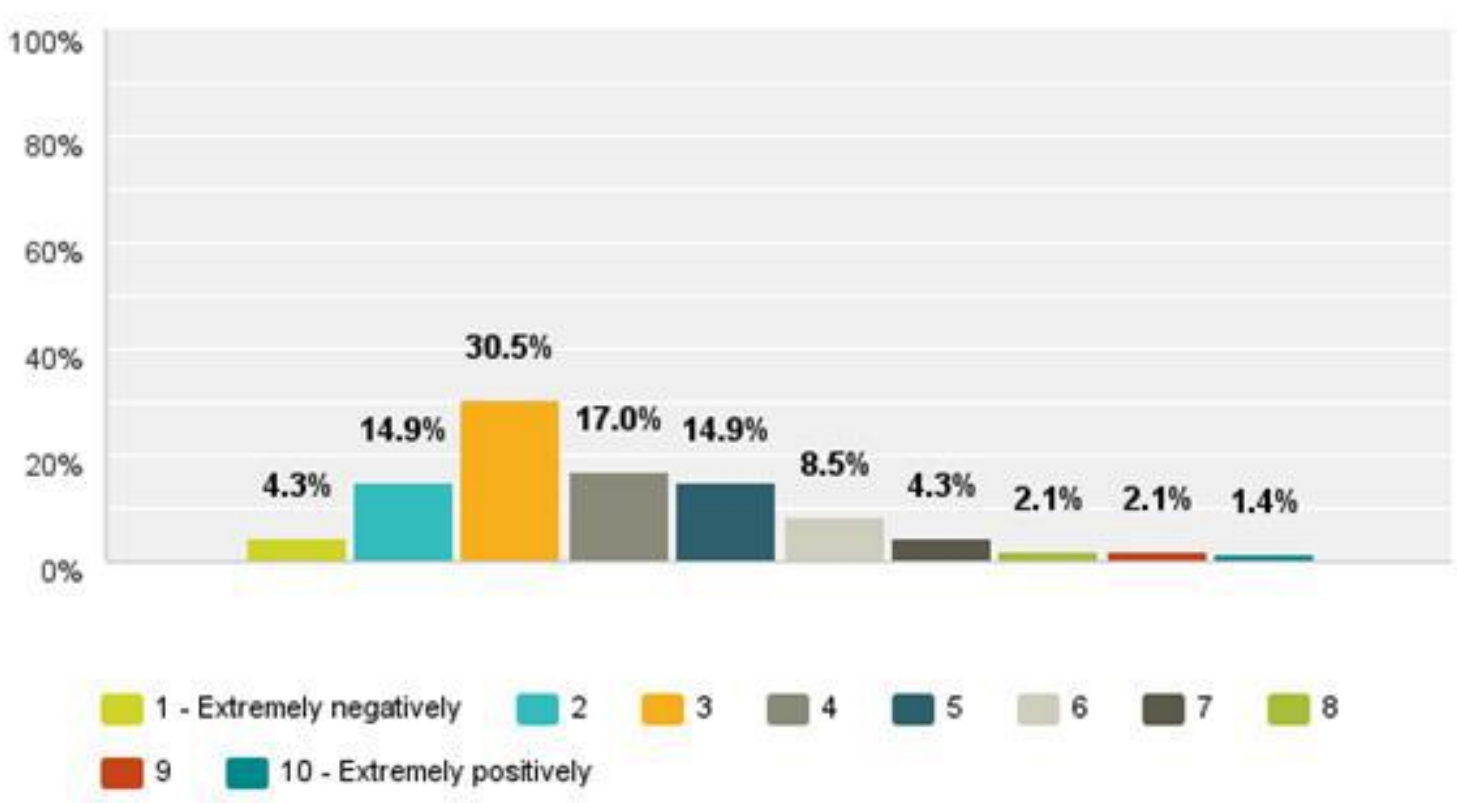

Table 4: Expected views of the general population (Source: Authors)

The mean average for this question is just 3.99, much lower than for their own attitude. The most common answer here (modal average) is just 3. Interestingly, with this question there is a significant variation between the different role groups:

\begin{tabular}{|lllll|}
\hline & $\begin{array}{l}\text { Mea } \\
\text { n }\end{array}$ & $\begin{array}{l}\text { Mod Minim } \\
\text { um }\end{array}$ & $\begin{array}{l}\text { Maximu } \\
\text { m }\end{array}$ \\
\hline Group & & & & \\
Consecrat & & & & \\
ed & 5.27 & 5 & 3 & 10 \\
Profession & & & & \\
al & 3.94 & 3 & 2 & 10 \\
$\begin{array}{l}\text { Lay } \\
\text { Person }\end{array}$ & 3.82 & 3 & 1 & 9 \\
\hline
\end{tabular}

Figure 4: Expected views of the general population by group (Source: Authors) 
Clearly lay people, who interact with non-Catholics on a daily basis, believe the Church is generally regarded less positively than those who represent it in official capacities.

Respondents were then asked what they considered to be the main reasons for the Church's less than positive image in society, from a list of suggestions. The suggested categories were developed from conversations (exploratory research) with the press office of the Catholic Bishops' Conference.

Answered: 140 Skipped: 40

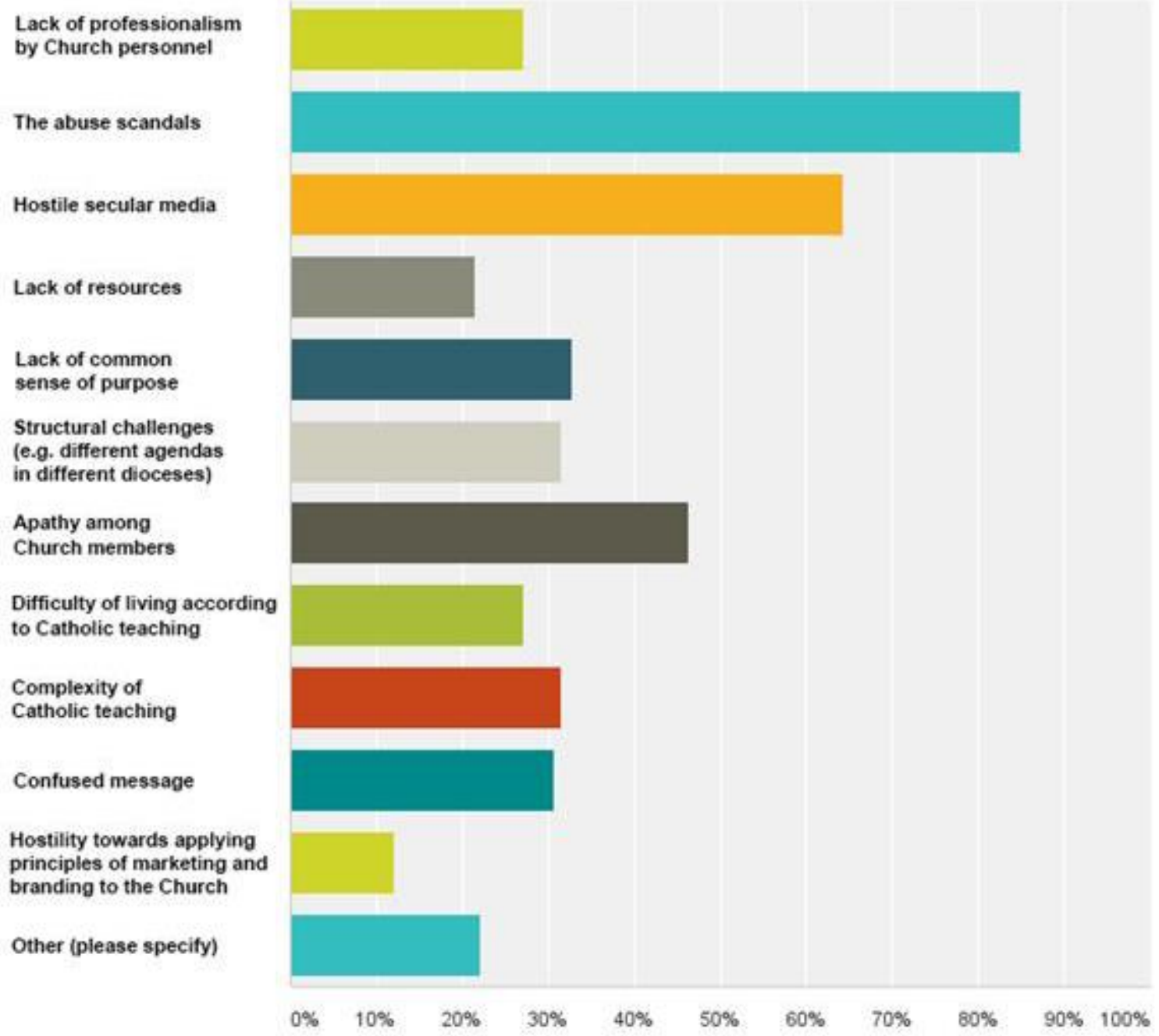

Table 5: Barriers to effective communication (Source: Authors)

It will be of no surprise to most people that the well documented abuse scandals within the Catholic Church are blamed for negativity towards the Church in society, and yet there is also 
a sense that the secular media is generally hostile to the Church anyway (and, by implication, unfairly so). Internal barriers such as apathy, structural challenges and difficulties with the message itself also figure significantly, although hostility towards applying principles of marketing and branding to the Church is not considered a major barrier - perhaps because many respondents do not think this would be appropriate or would be effective anyway.

As would be expected with a question such as this, other responses to this question painted a very challenging picture. Many respondents highlighted what they perceived as an intrinsically hostile agenda in the secular media and wider society. Others cited perceived barriers in the Church itself, such as ignorance and lack of understanding among ordinary Catholics, negativity and lack of vigour among the clergy and especially the bishops, and the poor quality of communications within the Catholic Church. Lack of clarity about what the objectives are of communications was also cited, as was a general sense of apathy among Church members.

\section{Solutions}

Finally respondents were asked what ideas, if any, they had to help the Church in England and Wales counter these challenges and a very wide range of suggestions were made. One theme to emerge was the need to professionalise communications within the Church. Others urged total openness and transparency within the Church, and the need for an adequate response to the abuse scandals was mentioned by some. Pope Francis, whose popularity transcends Catholic circles, was mentioned by a number of respondents, such as this one (a consecrated female aged 41-64):

"Pope Francis is doing a pretty good job in some areas. Watch \& learn might be a good starting point."

The need to remain positive, having clear communications objectives, investing more in training, focusing communications on young people, utilising the example of strong role models within the Church, ensuring messages are socially relevant and learning from other religious groups with strong brands were also mentioned. Some respondents also advocated changing controversial Church positions such as the male-only priesthood and priestly celibacy. Some thought the solution lay in more investment in communications and greater engagement with secular media. One respondent (a young, single lay Catholic) said: 
"More marketing and promotion. More openness and become a central part of culture as opposed to a subsection. General increase in awareness of people practising through TV, mass media adverts and marketing campaigns."

However, this view was not shared by all. One respondent (a lay married man) stated:

"People are justifiably suspicious of Marketing and Branding. These days politics is besieged by outliers who radiate authenticity at the expense of sophistication, contrived though it may be in many. The Church is poor at communicating and needs to improve urgently but it will need to be extremely judicious in applying the techniques of the secular marketplace."

\section{Conclusions}

\section{Application of 'brand' to the Catholic Church}

The literature review summarised the heated academic and theological debate about whether marketing and branding should be applied to religious organisations, and certainly this debate is reflected in the findings of this research. While some think strongly that the Catholic Church should adopt a more professional approach, including in the area of marketing, others think that to do this would be "profoundly inappropriate" and tantamount to sacrilege. The hostility towards branding does not seem to be against the Church having a brand per se but, rather, submitting itself to secular, commercial practices of marketing which are regarded as contradictory to the Church's nature.

A sizeable number of respondents (though not a majority) do consider the Church to have a brand, and only a minority said they thought using marketing and branding techniques to communicate the Church's message was not at all appropriate or not very appropriate. Indeed, hostility towards concepts of marketing and branding is, for the most part, a language issue. When asked what the objectives of marketing and branding should be, the most common answers were words like 'evangelise', 'communicate', 'promote' and 'attract'. These are to do with marketing and branding, but in Church parlance they are more sensitively termed 'mission'. There is clearly an appetite for more effective communication and a stronger sense of Catholic identity, and so it is concluded that the concept of brand can and should be applied to the Church, albeit couched in language that emphasises its spiritual rather than commercial objectives. 
It is clear from the research that there are many different views of what the Catholic brand is, and what the purpose of promoting it should be. The Catholic Church is not like a single commercial brand but is complex, multi-faceted and multi-dimensional. This makes it difficult to talk about a corporate brand identity for the Church, for even its leaders will hold different opinions and perspectives. This is one aspect of the fact that religion, while organised institutionally in the case of the Catholic Church, is nevertheless an intensely personal thing and everyone brings to it their own personal views and perspectives. Clearly the whole area of branding as it applies to religious and faith communities, and perhaps especially with regard to such a complex faith community as the Catholic Church, is underdeveloped in the academic literature and would benefit from further research.

\section{Perception of the Catholic brand}

The research indicates that there is a wide variety of views concerning the nature of the Catholic Church in England and Wales - ranging from descriptions that stress its social and community dimensions, through descriptions that stress its charitable nature, to deeply theological descriptions. This is understandable in such a large and diverse organisation, although it also demonstrates the lack of a clear corporate identity communicated from the top.

To use the language of marketing and branding there is a disparity between the Catholic brand as perceived by ordinary members of the Church (brand image) and the organisational identity proposed by its leaders (brand position) - or, at least, this is how it is perceived.

If one key finding from this research should be highlighted more than any other, it is the very high degree to which membership of the Catholic Church is important to its members' selfidentity. This is reflected to a considerable extent, although not wholly, in their positivity towards the Church even as they acknowledge that this positivity is not shared by nonmembers. This level of self-identification with being a Catholic, notwithstanding the challenges, disappointments and frustrations they speak of, shows the Church's remarkably strong brand equity. It is this strong brand equity and sense of identity, which managers of commercial brands could only dream of, that is the greatest strength of the Catholic brand and therein lies the greatest opportunity for those with a communications role within it. Despite the perceived shortcomings, this research identifies a number of very strong brand characteristics that could be built upon through effective brand positioning - including the Church's commitment to social justice, the sense of community it provides, the clear teaching 
it offers and its rites and ceremonies. However, the disparity of views demonstrates the complexity of doing this, especially without clear objectives.

Some research seeks to distinguish between brands and religion (e.g. Shachar et al., 2011, and Cutright et al., 2014) but it is argued here that this distinction is false. When viewed in terms of brand, one sees how complex but yet how strong the Catholic Church's brand is for its 'consumers' who define their sense of personal identity in relation to it and whose attitudinal and behavioural brand loyalty (Siala, 2014) and level of brand reliance (Shachar et al. 2011) are extremely high.

Having such a strong brand does not come without certain drawbacks for an organisation like the Catholic Church. Voas (2016, p.xviii) points out that "religious professionals also face the complacency of being free-riders on the reputation of their brands, letting quality and service standard drop without suffering any immediate loss" - precisely because of the very strong loyalty a religion's 'consumers' have to their brand. However, Voas warns that in the longer term, consumers do notice and rival 'suppliers' respond with alternatives in the form of "religious renewal, a process of rebranding or a new brand creation" (ibid.).

\section{Recommendations}

These conclusions lead on to a number of recommendations for more effective corporate communications within the Catholic Church in England and Wales. Specifically they deal with how the Church can leverage its strong brand equity and brand loyalty to the maximum with the objective of creating a stronger, more cohesive 'brand community' of more loyal and energised members (see Cutright et al, 2014).

Firstly, recognising the difference between how branding is applied to a commercial entity and to an organisation as complex as the Catholic Church will make the Church's communications stronger. With complex organisations like the Catholic Church come complex challenges, as can be seen in the complexities of brand perception within the Church - but so too come many opportunities when the Church's members are empowered to cobuild the brand and bring to it their own various skills, perspectives and experiences.

It therefore needs to be recognised that building an effective brand requires a greater commitment to genuine dialogue between leaders and ordinary members, without which the brand will not be co-built but could instead fracture into two distinct brands - the brand of the 
people and the imagined brand of its leaders. Many scholars agree that greater dialogue to build up a brand is more important than ever in this digital age, as with Grunig (2009) and his 'two-way symmetric' model which envisages a 50/50 co-orientation between organisations and their publics. While others have argued that this is just an ideal and almost impossible to practise, a refusal to engage in authentic dialogue will damage the cohesion of the Catholic brand.

From the aforementioned discussion of literature and the primary data findings we suggest that the church places more emphasis on public relations than it does on advertising. However, local churches do use the equivalent of display adverts and other marketing techniques. None of the public relations, marketing or advertising initiative appear to present a 'personality' (Kapferer, 2008) for the church brand as their core product, Jesus Christ, is in many ways the ultimate in personality branding.

There are of course limits to dialogue within the Church as the Church is communicating what it regards as non-negotiable truths. There has to be a sense of 'take it or leave it' to some extent and, in fact, this is one of the Church's strengths to many of its members who value the solid foundation it provides amid the shifting sands of this secular, post-modern age. This is why there is so much suspicion of the use of marketing and branding, because if in marketing the consumer's need is sovereign (see Wells, 1994), then it will necessarily bend or water down the truths of the faith to fit with consumer needs. However, if for 'marketing' we use 'mission' or 'evangelisation', and for 'brand' we use 'clear identity' and 'Gospel values', then the use of marketing and branding principles within religion are put within their proper context and are seen as tools compatible with the nature of an organisation that purports to represent a revealed truth. Sensitive use of terminology can help a lot.

The Church needs to be much clearer in its objectives for marketing and communications and the tools of marketing and communications will only work if this is so. The Catholic community in England and Wales is a 'broad church' in terms of the views and perspectives of its members, as this research has shown clearly, but this need not be a weakness. There is a need for greater clarity in the Church's message, more professionalism in the way this message is communicated and more confidence in the Church's own identity - and these things came out as strong themes in this research. It is the contention of this study that the objective should be to energise Church members by enhancing their sense of identity as Catholics, by celebrating and valuing this identity. For this to happen, all members of the Catholic Church in England and Wales need to be empowered to become brand ambassadors and communicators, not just the leaders and official representatives of the Church. This can be achieved through training but also through authentic two-way dialogue. 
Appealing to the imagination (see Abela, 2014) is a interesting and potentially highly effective way of communicating the Catholic brand more effectively, and it is without the ethical concerns inherent in more traditional forms of marketing which could be misconstrued as 'selling' the Church. It is a way of marketing the Church without commodifying it (a concern expressed by Usunier, 2014). Moreover, the Catholic Church is already adept at story-telling and can draw on almost 2,000 years of artistic, musical, literary and architectural appeals to the imagination of its members with the overall objective of communicating its core beliefs and messages. Other religions have equally noble and rich histories and their brands are communicated differently from that of the Catholic Church. Future research might focus on communication of other religious faiths and as such this paper acts as a baseline study from and against which benchmarks can be made, lessons learned and comparative analysis drawn.

By way of a final recommendation, it is useful to return to a question posed earlier - "Are then religions becoming brands while brands are becoming religions?" (Usnier and Stolz, 2014 , p.4). There cannot be a simple yes or no answer to this question, but this study does conclude that elements of branding and religion are increasingly informing and influencing each other, that religion is a 'concept brand' and that communications within the Catholic Church in England and Wales have the potential to be considerably improved and enhanced by leveraging this brand more effectively as within a true 'brand community'.

\section{References}

AAKER, J.L. (1997), 'Dimensions of brand personality', Journal of Marketing Research, Vol.34, No.3, pp.347-356

ABELA, A.V. (2014), 'Appealing to the imagination: Effective and ethical marketing of religion', Journal of Business Research 67 (2014) 50-58

ABREU, M. (2006), 'The brand positioning and image of a religious organisation: an empirical analysis', International Journal of Nonprofit and Voluntary Sector Marketing, 11: pp.139-146

BARTH, T. (2010), 'Crisis Management in the Catholic Church: Lessons for Public Administrators', Public Administration Review September / October 2010, pp.780-791 
CĂTĂLINA, M.C. and ANDREEA, P. (2014), 'Brands as a mean of consumer selfexpression and desired personal lifestyle', Procedia - Social and Behavioral Sciences,109, pp.103-107

CATHOLIC DIRECTORY OF ENGLAND \& WALES (2016). [Online], Manchester: The Universe, on behalf of the Catholic Bishops' Conference of England and Wales

COOKE, P. (2008), Branding Faith: Why some churches and nonprofits impact culture and others don't, Ventura, California: Regal

CUTRIGHT, K.M., ERDEM, T., FITZSIMONS, G.J. and SHACHAR, R. (2014), 'Finding Brands and Losing Your Religion?', Journal of Experimental Psychology, Vol. 143, No. 6, pp.2209-2222

DIETRICH, G. (2014), Spin Sucks - Communication and Reputation Management in the Digital Age, USA: Pearson Education, Inc.

EINSTEIN, M. (2008), Brands of Faith: Marketing religion in a commercial age, Abingdon: Routledge

European Institute for Brand Management (2009) Kapferer's Brand Identity Prism Model

GARCIA, C. (2010), 'Could it happen again? Catholic Church Image Repair Strategies in the Revocation of the Excommunication of the Four Lefebvrian Bishops', Public Relations Review 36 (2010) pp.70-72

GRUNIG, J. (2009), 'Paradigms of global public relations in an age of digitalisation', PRism $6: 2$

GUARDIAN (2015), "Cinemas refuse to show Church of England advert featuring Lord's Prayer" [online], 22 November 2015, www.theguardian.com/world/2015/nov/22/cinemachains-ban-advert-featuring-lords-prayer [accessed 9 December 2015] 
Kapferer, J. N. (2008) The New Strategic Brand Management - Creating and Sustaining Brand Equity Long Term ( $4^{\text {th }}$ edition$)$, London: Kogan Page

MOTTNER, S. (2008), Marketing and religion. In SARGEANT, A. and WYMER, W. (eds.), The Routledge Companion to Nonprofit Marketing, pp.92-107, Abingdon: Routledge

MULYANEGARA, R.C., TSARENKO, Y. And MAVONDO, F.T. (2010), 'An empirical investigation on the role of market orientation in church participation', International Journal of Nonprofit and Voluntary Sector Marketing 15, pp.339-351

NICHOLS, V. (2015), Homily for World Communications Day [online], 27 May 2015, www.catholicnews.org.uk/Home/Featured/World-Communications-Day-2015/Cardinal-sHomily [accessed 9 December 2015]

PHILLIPS, D. and YOUNG, P. (2009), Online Public Relations (Second Edition), London: Kogan Page (CIPR)

RATZINGER, J. (2004), Truth and Tolerance: Christian Belief and World Religions, (H. Taylor, Trans), San Francisco: Ignatius Press

SARGEANT, A. (2009), Marketing Management for Nonprofit Organizations ( $3^{\text {rd }}$ edition), Oxford University Press

SHACHAR, R., ERDEM, T., CUTRIGHT, K.M and FITZSIMONS, G.J. (2011), 'Brands: The Opiate of the Nonreligious Masses?', Marketing Science, Vol.30, No.1, Jan-Feb 2011, pp. $92-110$

SHEPHERD, I. D. H. (2004), 'Religious marketing: Reflections from the other side of politics', Journal of Public Affairs, Vol.4, No.3, pp.317-341

SIALA, H. (2014), 'Is There Such a Thing as Religious Brand Loyalty?' In USUNIER, J. and STOLZ, S. (eds), Religions as Brands: new perspectives on the marketization of religion and spirituality, pp.141-155, Burlington, VT: Ashgate 
THOMPSON, D. (2013), “Has Pope Francis contaminated the Catholic brand?”, Telegraph blogs [online], 29 July 2013,

http://blogs.telegraph.co.uk/news/damianthompson/100228472/has-pope-francis-

decontaminated-the-catholic-brand/ [accessed 9 December 2015]

TILDESLEY, A.E. and COOTE, L.V. (2009), 'This Brand Is Me: a Social Identity Based Measure of Brand Identification', Advances in Consumer Research Volume 36, eds.

McGILL, A.L. and SHAVITT, S., pp. 627-628, Duluth, MN : Association for Consumer Research

TWITCHELL, J.B. (1999), Lead us into temptation: The triumph of American materialism, New York, NY: Columbia University Press

Twitchell, J. B. (2004) Branded Nation: The Marketing of Megachurch, College, Inc., and Museumworld, New York, Simon and Schuster

USUNIER, J. (2014), ““9591”: The Global Commoditization of Religions through GATS, WTO, and Marketing Practices'. In USUNIER, J. and STOLZ, S. (eds), Religions as Brands: new perspectives on the marketization of religion and spirituality, pp.27-43, Burlington, VT: Ashgate

USUNIER, J. and STOLZ, S. (2014), 'Introduction'. In USUNIER, J. and STOLZ, S. (eds), Religions as Brands: new perspectives on the marketization of religion and spirituality, pp.325, Burlington, VT: Ashgate

VOAS, D. (2014), 'Preface'. In USUNIER, J. and STOLZ, S. (eds), Religions as Brands: new perspectives on the marketization of religion and spirituality, pp.xvii-xiv, Burlington, VT: Ashgate

Voas, D. and Chaves, M. "Is the United States a Counterexample to the Secularization Thesis?," American Journal of Sociology 121, no. 5 (March 2016): 1517-1556. 
WELLS, D. (1994), God in the Wasteland, Grand Rapids, MI: Eerdmans

WITKIN, R. (2014), 'Religion Has Become Toxic Brand In The UK, New Study Shows, The New Civil Rights Movement [online], available at

http://www.thenewcivilrightsmovement.com/rachelwitkin/more_than_half_of_british_people _think_religion_does_more_harm_than_good [accessed 1 May 2016]

WOODHEAD, L. (2014), 'Time to get real', Church Times, $31^{\text {st }}$ January 2014 [online], available at https://www.churchtimes.co.uk/articles/2014/31-january/features/features/timeto-get-serious [accessed 1 May 2016]

Wymer, W. Jr., Knowles, P. and Gomes, R. (2006), Nonprofit Marketing, California: Sage Publications 